\title{
Maternidade Segura e Planejada
}

Dados da OMS, 2001, revelam que, anualmente, em todo o mundo, 515 mil mulheres morrem por complicações da gravidez e do parto. Outros sete milhões de sobreviventes padecerão com sérios problemas de saúde provindos de complicações surgidas na parturição e outros 50 milhões estarão estigmatizadas com algum tipo de seqüela.

Em 98\% dos eventos, os fatos acima ocorrem em países subdesenvolvidos ou em vias de desenvolvimento. Algo deve ser feito para minorar estas cifras deprimentes.

Também em 2001 a OMS publicou relatório defendendo a Maternidade Segura no séquito, e obediência, aos direitos fundamentais da pessoa humana.

Cinco itens foram considerados relevantes: Direito à Vida / Direto à Liberdade e Segurança Pessoal / Direito a Nivel Adequado de Saúde / Direito à Proteção na Maternidade / Direito à Não Discriminação da Mulher. Consideremos, brevemente, algo relacionado à Saúde e Proteção à Maternidade.

É inquestionável o Direito de cada cidadão, e de cada mulher grávida, a níveis aceitáveis de saúde, física e mental. Como ambicionar este Direito, universal, com tantas barreiras econômicas, sociais e culturais?

No nosso entender o cerne do problema, de modo especial no que se refere à maternidade em adolescentes, reside no abandono educacional e cultural destas jovens mães. O ensino, a educação fundamental, obrigatórios, rigorosamente controlados, anulariam ou reduziriam a cifras irrisórias o percentual de adolescentes grávidas, com pais desconhecidos, perambulando por nossas megalópoles.

Qual o porvir destas gestações seja para a mãe seja para a prole? A maternidade prematura, indesejada e acidental, tolherá as oportunidades de crescimento na atividade laborativa ou no crescimento intelectual destas jovens. Por outro lado, a prole será precocemente abandonada elevando o contingente de crianças e adolescentes relegados em nossas grandes cidades, candidatos férteis para a criminalidade.

É tema para profunda, séria e premente reflexão. A saúde física e mental das mães, e da prole, está indissociada da educação básica com os conhecimentos fundamentais de higiene pessoal e direcionamento da sexualidade para o nobre fim da reprodução, na época oportuna, com todas as garantias de Maternidade Segura e Planejada.

A Diretoria 